driving force from a given area' where, in fact, the designer's primary objective is only to get the best driving force out of hull and crew and whatever rig they can handle. Also 'heeling force should be kept to a minimum ', where the designer's objective is often to make use of the heeling force to stabilize the motion. There was, throughout the conference, something of an inbuilt condescension towards existing local craft and an assumption that we would all be best to start again.

The conference was also told that there are large numbers of bankers and general funding authorities interested in the wind-assisted propulsion concepts. The equipment is available, the technology is present and fuel savings of 25 per cent or more reliably reported. The ship owners and operators however would not seem to be convinced. They, apparently ignoring this financial bonanza, are spending their money and their personal efforts on detail changes to their existing power units. By means of minor changes in fuel formulation and operating procedures they seek to save some 2 or 3 per cent of their fuel costs. There must be some other factors involved, and it may be that the wind-assisted propulsion exponents are only considering the efficiency of that part of the overall operating picture which has taken their eye.

It may be, for instance, that potential delays in harbour due to handling cargo around the rig or potential delays to repair delicate WAP equipment may reduce the apparent reliability of voyage timing. The costs of the late delivery of a cargo by even a few hours might involve extensive peripheral cost with lorries and trains and so on standing by for them. WAP now has ample evidence of quite outstanding results, but perhaps now needs to have its targets redefined.

C. Mudie

\title{
Dr D. H. Sadler, OBE
}

DONALD HARRY SADLER, astronomer, an Honorary Member, Gold Medallist and former President of the Institute, died peacefully at his home in Sussex on 24 October 1987. He was 79.

As Superintendent of H.M. Nautical Almanac Office from 1937 until 1970 Sadler was responsible for the preparation, design and production of the Nautical Almanac (Astronomical Ephemeris since 1960), the Abridged Nautical Almanac (Nautical Almanac since 1960), the Air Almanac and the Star Almanac for land surveyors as well as a number of ephemerides and mathematical tables intended for astronomers. He was also responsible for the production in this country of the altitude-azimuth tables published jointly in the United Kingdom and United States Sight Reduction Tables for Air Navigation, AP 3270 , Tables of Computed Altitude and Azimuth, HD 486 and Sight Reduction Tables for Marine Navigation, HP 401 .

The introduction in 1937 of the Air Almanac based on Greenwich hour angle was largely due to Dr Sadler and he designed the Astronomical Navigation Tables for use with it. These tables became the standard method of tabular sight reduction in the Royal Air Force and the United States Air Force and were widely used at sea, particularly just after the war before the introduction of the GHA Nautical Almanac and appropriate nautical tables. During the war his work for air navigation was closely bound up with that of the Empire Air Navigation School and his sympathy and understanding of the problems of the practical navigator enabled him to make enormous improvements in tables and methods. His investigation into the effect of the Coriolis acceleration on bubble sextant 
observations (described in the first number of the Journal) was of fundamental importance. Later, after a thorough inquiry into the special features of high-latitude navigation he was to design tables for astronomical polar navigation. It was during this period that NAO produced the astrograph, a device by means of which graphs for two (or sometimes three) stars reproduced on film could be projected and the latitude and longitude of a fix from the altitude of the two (or three) stars obtained by plotting.

The redesign of the (then Abridged) Nautical Almanac for 1952 on the basis of Greenwich hour angle was undertaken by NAO after much research and an inquiry, conducted largely through the Institute, into how the proposed changes were likely to be received at sea. The new form of almanac was widely appreciated and remains a tribute to Sadler's skill as an almanac-maker. The 1952 edition in particular was a typographical masterpiece, although later unification with the United States publication necessitated changes of style.

As a maker of almanacs Dr Sadler was clearly in the front rank and his 1956 edition of Interpolation and Allied Tables was widely held to be an indispensable tool for the computer of navigation tables. He also made important contributions to the techniques of computing Decca lattices for which the NAO had assumed responsibility. Comparatively recently he designed the ephemeris section of the Macmillan and Silk Cut Nautical Almanac and the sight reduction tables printed in the Macmillan and Silk Cut Yachtsman's Handbook; the latter, intended primarily as a back-up method for emergency use when a calculator is not available, are of particular interest in that they foresake the intercept method in favour of the Sumner line.

Although few books appear under his name, Sadler's contribution to the literature of astronomical and mathematical navigation is massive. Some eighty papers, reviews and notes have been published in the Journal alone, many of them of fundamental importance describing original work. His complete mastery of the subject, his understanding of the navigator's task and the purity of his style make them a memorable collection.

Dr Sadler received many awards, most of them relating to his work as an astronomer. He also received the Thurlow Award of the US Institute of Navigation, of which he became an Honorary Member in 1979 and this Institute's Gold Medal in 1957 followed by Honorary Membership in 1973 . He was Secretary of the Royal Astronomical Society from 1939 to 1947 and its President from 1967 to 1969 . He was General Secretary of the International Astronomical Union from 1958 to 1964 and President of the Federation of Astronomical and Geophysical Services $1969-70$.

Donald Sadler was President of the Institute from 1953-5. He had been a member of the original Steering Committee, the Provisional Council and the first Council, elected in 1947. He had a profound influence on the character of the Institute in its formative years, appealing always to the traditions of the learned and scientific societies in this country as against the more limited objectives of the professional bodies concerned largely with their members. It was Sadler who coined the epigram The Institute is of Navigation and not of Navigators, a thought that was years later to illuminate many of the discussions on the Institute's future by the Way Ahead Group.

Sadler played a leading part, perhaps the leading part, in the formation of the International Association of Institutes of Navigation and was responsible for framing its Constitution. Here his experience with the International Astronomical Union was invaluable to the nascent body.

As an editor Dr Sadler's experience was profound and extensive. He understood every part of the editorial process and his standards, of presentation as well as content, were rigorous. As Editor of the Journal I learned much from him and was sustained over nearly forty years by his interest, help and support as well as the occasional criticism. He was 
the ideal referee, sure of his ground, critical, articulate but always willing (when he thought it worthwhile) to help the author improve his paper, or the Editor to refuse it gracefully.

The Institute, of which he was a founding father, meant much to Donald Sadler and it was sad that he was just to miss the fortieth anniversary dinner, an event he was much looking forward to. As the President remarked on that occasion, perhaps no individual in the Institute's history has devoted so much time and effort to its well-being. His influence will remain.

M.W.R.

\section{Salute to Donald Sadler From a Fellow}

It was on the night of the Annual General Meeting when I learned of the news about Donald. On getting back home, and locking up outside, and then looking up outside, the sky, the finest for many a long time, was studied. Not a cloud anywhere, and not one star was absent. How appropriate, and how glorious, a salute to an old friend!

\section{Blondie Hasler}

Herbert George Hasler, universally known as Blondie, died in Scotland after a short illness at the age of 73 . He was not a member of the Institute although he contributed to the Journal on a number of occasions. Through his invention of the first reliable wind-vane steering gear and his radical views on yacht design he had a profound influence on the conduct of long-distance voyages in small boats. The following is the text of the address by Michael Richey at the service of thanksgiving held in Portsmouth Cathedral on 19 June 1987.

One of the reasons I am here to pay a tribute to Blondie Hasler is that some 20 years ago, in 1965, I bought his yacht Jester after he had completed four single-handed transatlantic passages in her. I knew him before that, although not well, but Jester first gave me an insight into that brilliant, unorthodox and fertile mind. The boat, with her full enclosure and unstayed mast was a stroke of genius, of which Angus Primrose would later say she represented the only significant advance in yacht design this century.

With the boat I inherited a notebook relating to her design and construction which to someone of a more slap-happy disposition became a source of wonderment. The detail was extraordinary, from scale drawings of a man performing all the functions he might be expected to in a boat - sleeping, eating, cooking, navigating and so on - to the dimensions of a biscuit tin. Jester had been no shot in the dark but the result of careful thought and a radical approach to the problems of seamanship.

This measured approach was characteristic of Blondie in everything he undertook. Combined with an inventive streak it resulted in a wide range of original ideas to do with boats and the sea. Jester herself scarcely qualifies as an invention, but for her first transatlantic crossing in 1960 she was fitted with a wind-vane steering device which enabled her to complete the passage almost entirely under self steering. Nowadays when such equipment is commonplace it is difficult to realize how revolutionary a concept this was. For the first time in the long history of sail a boat could be reliably steered on all points of sailing without the help of a helmsman. If for nothing else Blondie would be remembered for that. 